\title{
Health communication: mother's knowledge and treatment of fever in children
}

\author{
Geby Mora \\ Sekolah Tinggi Ilmu Kesehatan Yatsi, Tangerang, Indonesia \\ moragebymor@gmail.com \\ Ria Setia Sari \\ Sekolah Tinggi Ilmu Kesehatan Yatsi, Tangerang, Indonesia \\ riasetia@gmail.com \\ Febi Ratnasari \\ Sekolah Tinggi Ilmu Kesehatan Yatsi, Tangerang, Indonesia \\ febiratnasari@gmail.com
}

\begin{abstract}
Fever is in the first place of some of the most symptoms experienced by the child, the treatment of fever depends heavily on the role of parents especially the mother, The lack of knowledge possessed by the mother causes misperception of fever, this misperception results in inappropriate behavior in dealing with fever in the child then it is necessary to know further the level of maternal knowledge and treatment of fever in the child. This literature is to analyze journals on the level of maternal knowledge and the treatment of fever in children. The design of the research used in this study was literature review. This literature study through scientific publication search results with the range of 2015-2020 using the Research Gate, NCBI, Ebsco and Google Scholar databases.journals that correspond to the title and results of the synthesis matrix grouped into three parts namely input, process and output. Of the 20 articles analyzed entirely showed there is a link between maternal knowledge level and fever treatment in children, the average result of $45 \%$ of mothers with good knowledge level and $57.87 \%$ of mothers handling fever in children appropriately.
\end{abstract}

Keywords: Fever in Children, Maternal Knowledge, Fever Management.

\section{Introduction}

Fever is a condition when the human body temperature increases from its normal temperature above $37^{\circ} \mathrm{C}$. Fever is one of the many symptoms when a person's body has an infection or disease (Cahyaningrum, 2017). The main cause of fever in children according to 
Widagdo (2012) is due to typhoid fever, respiratory tract infections, measles, and gastrointestinal infections.Currently fever is in the first place of the most symptomatic emoat experienced by children namely fever $33.4 \%$ cough $28.7 \%$ cough and fast breath $17.0 \%$ and diarrhea $11.4 \%$. Based on the results of a survey conducted by the National Family Planning and Population Agency in 2017, in Indonesia the prevalence of fever of children aged 6-23 months is more susceptible to fever (37-39\%)

In essence, humans are creatures who are born weak and helpless, but in so doing he already has inherent potential which is latent (Subqi, 2016). Humans are social creatures who need to interact with other people in their lives and help each other out (Subqi, no date).

Complications that threaten a child's safety such as seizures and even decreased consciousness can occur if not treated properly and quickly (Maharani, 2011).In fever with a temperature of $41^{\circ} \mathrm{C}$ the risk of death reaches $17 \%$, and when it reaches $45^{\circ} \mathrm{C}$ will result in death in the child in a short time (Said, 2014).In Indonesia as much as 465 (91.0\%) of the 5511 mothers used the technique to find out their child's body temperature was only $23.1 \%$ using a thermometer (Setyowati, 2013).The technique of perpetuation to know body temperature is highly discouraged due to temperature inaccuracies and cannot be known if body temperature increases rapidly to a dangerous level.

The mother's knowledge of fever in the child can be a reference to the mother's attitude how to deal with fever in her child.children who have fever require special treatment when compared to fever in adults, because it will cause adverse effects that are impaired development and growth of the child if the treatment in coping with fever is done inappropriately and quickly. Low-knowledge mothers are at seven times the risk of treating fever less well than higher-knowledgeable mothers (Siagian and Manalu, 2018). Research conducted by (Rasinta, 2017), 2017) to 57 mothers who have toddlers. The results of the study of 18 respondents $(31.6 \%)$ with less knowledge. 28 respondents (49.1\%) Still bad. The results of the 2013 National Health Survey showed that 20-25\% of children died from maternal error treating fever in their child.

The treatment of fever given to the child depends heavily on the role of the parents, especially the mother.Mothers who have knowledge of fever and have a positive attitude in providing care can determine the 
best fever treatment for their child.Phobias against fever were experienced by mothers in the results of the study, he explained the results that $80 \%$ of parents have a phobia of fever.Many of them (mothers) assume that if fever is not given treatment then the body temperature will increase further.As a result of this misperception, in the study showed that $50 \%$ of parents give a drug to treat fever in their child known in a non-self management way (Cahyaningrum, 2016). Parents who immediately give fever-lowering drugs to their children who actually have a mild fever that does not require medication. As an early treatment that can be done by the mother is to compress the feverish child with warm water.

The general purpose of this study is to analyze and compare several journals or research articles and whether there is a Link between Maternal Knowledge Level and Fever Management In Children.

\section{Method}

This literature review is compiled through the approval of several relevant sources and has been published from various sites namely Research Gate, NCBI, Ebsco and Google Scholar.In the search for articles using Bahasa Indonesia and English with the keyword "Fever in Children/ Fever in children, Maternal knowledge, Fever Treatment Publication, period of articles 2015 to 2020.

In the search for articles identified 132 articles, after the selection process obtained 20 articles based on inclusion and exclusion criteria.It is then incorporated into the synthesis matrix to divide several groups and classify different arguments from several articles and combine the different elements to get the impression/conclusion of the entire article in general (Rasimin, 2018) 


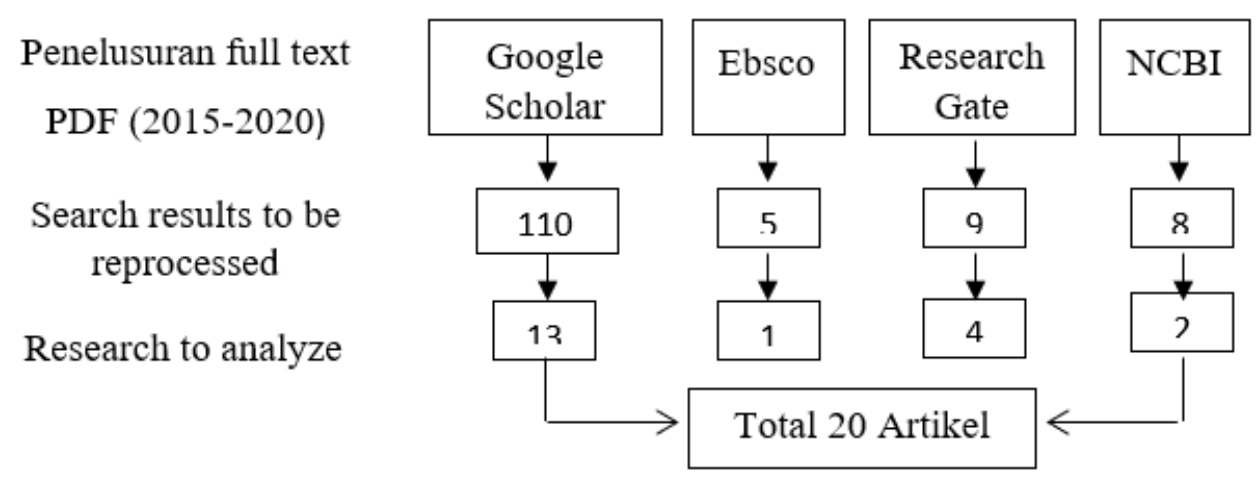

\section{Results}

This literature review studied 20 Journals of Nasioanl and International, quantitative descriptive research using cross sectional study design.In summarizing the journal, the author created a matrix of journals in a table that contains the names of the researchers, samples and methods used, the title of the study, the source and the results/conclusions. There were 20 journals that had been in the esktraction in the journal matrix.

The author also used a synthesis matrix that was a diagram/table that would divide several groups and classify a variety of different arguments from several articles, consisting of, 1) Input: a. Factors that affected the mother's knowledge, were education, age, occupation, socioeconomic, number of children, advice from health workers, the history of children who have been hospitalized. $b$. Mother knowledge level, obtained different results from each city and sengara ranging from $28.1 \%$ to $68.1 \%$ well-knowledgeable mothers. The average number of well-knowledgeable mothers is $45 \%$. 2) Process: Treatment of fever in children, the average resulted from 7 journals were $46.90 \%$ to $68.10 \%$ of mothers handled fever well, an average of $57.87 \%$ of mothers handled fever well, and 7 other journals showed that $32.90 \%$ of mothers used antipyretics to overcome fever. 3) Ouput: the relationship between the level of maternal knowledge and the treatment of fever in the child, it was concluded that the level of knowledge affects the treatment of fever, there were still many mothers who lack knowledge about fever and how to deal with it. 


\section{Discussion}

In the study conducted by Butar-butar in 2018 obtained results in knowledgeable mothers with poor handling category as many as 12 respondents $(80.0 \%)$, Chi-Square test results obtained a value $(\mathrm{p}=0.001$ $>0.05$ ) can be concluded that there is a relationship between the knowledge and attitude of the mother about fever and the treatment of fever in the child.

Abdinia Research (2017) shows that there is a significant link between parental education and the use of antipyretics and antibiotics in treating fever in children with scores of $p=0.041$ and 0.0013. Then there is the relationship between history and hospitalization of children with the use of antipyretics and antibiotics in treating fever with scores of $p$ value 0.01 and 0.04 , and there is a link between the age of the child and the frequency of parents visiting a doctor $p=0.046$. According to the results of bong research (2018) the level of education affects knowledge about fever, parents from high income groups have better knowledge compared to other income categories, p-value $(<0.001)$. so the higher the level of Education and income that individuals have then the better the knowledge.

In research conducted by Aulia (2019) shows that of the $28.1 \%$ of well-knowledgeable mothers, the low level of knowledge in mothers is influenced by employment status where as many as 47 people $(82.5 \%)$ is IRT.In this study respondents faced difficulty getting information about fever.Fever treatment is good at $29,8 \%$.there is a link between attitude and fever treatment of chi-square test results $(\mathrm{p}=0.01<0.05)$.

According to journal 8 by Anokye,et al shows the results that house management fever by giving a warm sponge (28\%) and visit the nearest hospital (62\%). as many mothers (65\%) herbal medicine when the child has a fever, paracetamol (71\%) and chlorokuin (62\%) as a remedy for overcoming fever.It is concluded that the knowledge that parents have about fever management fever is still bad.

\section{Conclusion}

The level of maternal knowledge is influenced by various factors namely education, age, occupation, socioeconomic, number of children, advice from health officials, the history of the child who has been 
hospitalized.Based on literature review results researchers found that there are still many mothers who have less knowledge about fever perception and fever treatment in children.It can be concluded that there is a relationship between the level of maternal knowledge and the treatment of fever in the child.The higher the level of knowledge about fever the better and wiser the treatment of fever carried out when the child has a fever.

\section{Bibliography}

Abdinia, B., Kargar Maher, M. H., \& Khalilzadeh, H. (2017). Assessment of knowledge and performance of the parents at the management of fever in children. International Journal of Pediatrics, 5(12), 6485-6493. https://doi.org/10.22038/ijp.2017.26876.2317

Aulia, R. (2019). Hubungan Tingkat Pengetahuan Dan Sikap Ibu Tentang Demam Dengan Penatalaksanaan Demam Pada Anak Di Puskesmas Harapan Raya Pekanbaru. Jurnal Ilmu Keperawatan (Journal of Nursing Sciences), Volume 8,. https://doi.org/p-ISSN: 23382112 e-ISSN: $2580-0485$

Bong, W. T., \& Tan, C. E. (2018). Knowledge and concerns of parents regarding childhood fever at a public health clinic in Kuching, East Malaysia. Open Access Macedonian Journal of Medical Sciences, 6(10), 1928-1933. https://doi.org/10.3889/oamjms.2018.339

Butarbutar, M. H., Sholikhah, S., \& Napitupulu, L. H. (2018). Preventif: Jurnal Kesehatan Masyarakat the Relationship of Knowledge and Attitude About Fever and Its Treatment in Children At Shanty Clinic Medan. 2, 53 57. Retrieved from

http://jurnal.untad.ac.id/jurnal/index.php/Preventif

Budyastomo, A. W. (2018) 'Bentuk Bahasa Komunikasi Dalam Seni

Grafiti Sebagai Media Penyampaian Pesan (Studi Kasus: Padepokan Grafiti Salatiga)', Batoboh, 3(2), p. 146. doi: $10.26887 /$ bt.v3i2.527.

Cahyaningrum, E. D. (2016). Penatalaksanaan anak demam oleh orang tua di puskesmas kembaran I banyumas. Viva Medika, 09(17), 44-53. Retrieved from https://ejournal.uhb.ac.id/index.php/VM/article/view/127

Cahyaningrum, E. D., \& Putri, D. (2017). Perbedaan Suhu Tubuh Anak 
Demam Sebelum Dan Setelah Kompres Bawang Merah. Jurnal Ilmiah Ilmu-Ilmu Kesehatan, XV(3), 12. Retrieved from http://jurnalnasional.ump.ac.id/index.php/medisains/article/view/ 1642

Maharani, L. (2011). Perbandingan efektifitas pemberian kompres hangat dan tepid water sponge terhadap penurunan suhu tubuh balita yang mengalami demam di Puskesmas Rawat Inap Karya Wanita Rumbai Pesisir (Universitas Riau). Retrieved from https://www.scribd.com/doc/73195543/all-ok

Rasinta, H. (2017). Hubungan Tingkat Pengetahuan Ibu tentang Demam Dengan Cara Penanganan Pada Balita Di Desa Bedoro Kecamatan Sambungmacan Sragen. UMS ETD-Db Repository.

Rasimin. (2018). Metodologi Penelitian Pendekatan Praktis Kualitatif. Yogyakarta. Trussmedia Grafika

Ria Setia Sari, F. P. (2017). Hubungan Pengetahuan Ibu Tentang Gizi Seimbang Dengan Perilaku Pemenuhan Gizi Pada Balita Usia 3-5 Tahun di Wilayah Kerja Puskesmas Periuk Jaya Kota Tangerang. Jurnal Kesehatan, $6(3)$.

https://doi.org/https://doi.org/10.37048/kesehatan.v6i3.12

Said. (2014). Perbedaan Pengetahuan Ibu Sebelum Dan Sesudah Diberikan Penyuluhan Tentang Penaganan Anak Dengan Demam

Panas Di Wilayah Kerja Puskesmas Manggala Kabupaten Tulang Bawang Tahun 2014.

Setyani. (2014). Gambaran Prilaku Ibu Dalam Penanganan Demam

Pada Anak Di Desa Seren Kecamatan Purworejo (STIKES

Aisyiyah). Retrieved from Digilib.unisayogya.ac.id/549/

Setyowati, L. (2013). Hubungan Tingkat Pengetahuan Orang Tua

Dengan Penanganan Demam pada Anak Balita di Kampung Bakalan Kadipiro Banjarsari Surakarta. STIKES PKU Muhamadiah Siagian, E. and Manalu, V. (2018) 'Health Education based on 10 Steps at Mother Knowledge Level in Handling Febrile Seizure on Toddler', Journal of Nursing Care, 1(3). doi: 10.24198/jnc.v1i3.19104.

Subqi, I. (2016) 'Pola Komunikasi Keagamaan dalam Membentuk Kepribadian Anak', Interdisciplinary Journal of Communication (Inject), 1(1), pp. 165-180.

Subqi, I. (2020) 'Nilai-nilai Sosial-Religius dalam Tradisi Meron di 
Masyarakat Gunung Kendeng Kabupaten Pati Socio-Religious Values of the Meron Tradition in Mount Kendeng Community At Pati Regency', 1(2), pp. 171-184. 